Vol. 4, No. 1, 2017

\title{
INSTRUMENTS OF PROPAGANDA: THE BURIAL PLACES OF THE SOVIET SOLDIERS OF THE SECOND WORLD WAR IN LITHUANIA. OLD AND NEW TRENDS
}

\author{
Salvijus Kulevičius \\ The Faculty of History of Vilnius University
}

(C) Salvijus Kulevičius, 2017

\begin{abstract}
Місця поховання солдатів Радянського Союзу Другої світової війни с місцями вторинного поховання, створеними в Литві переважно в 1945-1956 рр. Вторинне поховання нібито позбавило історичної конкретики (автентичності місця, персоналізації) і дало змогу створювати їх відповідно до політичних та ідеологічних потреб конкретного періоду. В 1990-ті в Литві відбувалась девальвація міфа Великої Вітчизняної війни. Пам'ятники Перемозі і героям війни були демонтовані та із звичних громадських місць перетворились на експонати й розвалені об'єкти парку Груто. Місця поховання солдатів Радянського Союзу, по суті, ніхто не заторкував і вони застигли впродовж одного чи двох десятиліть. У 2000-2010 рр. ці місця отримали актуальність, але вже не як засіб пропаганди однієї ідеології, а як об' скти зіткнення декількох видів пам'яті. Цвинтарі радянських солдатів Великої Вітчизняної війни стали «Цвинтарями радянських солдатів, що загинули в 1941-1945 рр.» і «Місцем поховання солдатів Радянського Союзу Другої світової війни». Різні назви того самого об'скта свідчать про його різну оцінку.

Проаналізовано процес і ситуацію, як ці місця в Литві останнім часом (з 2000 р.) за гроші Російської Федерації і після реконструкції отримали новий вигляд, вигідний для поширення чужої ідеології та суперечливої «головній лінії» політики пам'яті Литви.
\end{abstract}

Ключові слова: Друга світова війна, Литва, політика пам'яті.

Instead of an Introduction: The Existence of Myth. There was a time when the myth of the Great Patriotic War prevailed in the whole territory of the Soviet Union. It was an extremely obvious and vivid creation of propaganda and politics of memory. It was created to maintain the system and engrain necessary attitude. The narrative of not so old past had to construct the present and in order to better serve its aim, the narrative itself was constructed on the grounds of falsification or at least not trying to avoid it. And, as it is typical to such creations, they must unconditionally be believed in and relied on. The myth was binding on the entire territory of the Soviet Union and was compulsory in the form dictated by the centre. There was no place for variations. Such situation lasted up to 1990. After the collapse of the Union, the fate of myth was different in its different former territories. It seems that today it is being rethought in Ukraine. In 2010 the Lviv Oblast Council of Ukraine and in 2015 the Ukrainian Parliament decided not to use the concept of the Great Patriotic War. The change of concepts reveals an attempt to reinterpret the events and redo the memories. Its seems that the theme of World War II has not disappeared from the horizons of memory of Ukrainians - it still remains the value on the grounds of which they attempt to create their own myth - the great national narrative, which is isolated from the interpretations spoken by the Soviet and present Russia. A good illustration of this fact could be the expositions of the National Museum of the History of Ukraine in the Second World War (up to 2015 its official name was the National Museum of History of the Great Patriotic War of 1941-1945).

From the presentation of exposition on the Museum's website (in English):

The main exhibition of the National Museum [...] has more than 17 thousand exhibits that reflect the greatest military conflict of the 20th century - the Second World War and emphasize the contribution of the Ukrainian people in the achievement of the victory over Nazism. The Ukrainian factor in the exposition wasn't chosen randomly because about $60 \%$ of the Wehrmacht divisions and $50 \%$ of the Red Army units were involved in active hostilities in the territory of Ukraine which lasted for 35 months. Every fifth soldier of the Soviet Army was of Ukrainian origin. [...] hundreds of thousands of patriots fought in the ranks of the National Liberation Movement against Nazi and Communist dictatorships for freedom and independence of Ukraine ${ }^{1}$.

From the exposition stand (2016, in Ukrainian):

The parents, grandparents and ancestors [...] of current "cyborgs" - the participants of the Second World War [stand] in one line with them to confirm the

1 "Main Exposition", in: National Museum of the History of Ukraine in the Second World War. Memorial Complex, [interactive], in: www.warmuseum. kiev.ua/_eng/expositions/main_expo/index.html, (05/04/2017). 
continuity of the military traditions of the Ukrainian people.

The Ukrainian content is intended to be given to the Second World War by turning the Victory in this war into the victory of Ukrainians and the war itself turning to the struggle for freedom of Ukraine. Manifestation is also the subject of strive: today the heroes of the Second World War who are rather of qualitative or moral category than specific heroes who are themselves considered to be of value, stand on the side of the Ukrainian people and today's Ukrainians are duly following their path.

The Lithuanian people went the other way. Despite the pluralism of today's pro-Lithuanian memories, ${ }^{2}$ one tendency prevails - these memories are unfavourable to the myth of the Great Patriotic War. The myth means nothing to these memories - it is invisible, uninfluenceable and irrelevant. For the myth it actually equals death. Sometimes it even annoys - i.e. causes negative associations and defensive reactions. The previous/present thematic or valuable accents of the myth are rejected as anti-values or threats: victory/occupation, liberation/occupation, liberators/occupants. The myth tells about the victory in the war and liberation of Lithuania against the German fascists, while the official outcome of the Second World War (1944-1945) for Lithuanians associate with the loss - the Soviet occupation; for Lithuanians it's not a victory and not the end. They perceive it as a beginning of something not less cruel and painful. The Second World War is not interesting for pro-Lithuanian memories and narratives. The events that occurred after 1944-1945 are the most significant to them. That's where the great national narrative of Lithuanians begins - the fights of Lithuanian partisans (1944-1953). The political and official position of Lithuania on the issue of the Great Patriotic War was very clearly expressed in 2005, when the President of the Republic refused to go to Moscow to commemorate the 60th anniversary of Victory. And this position still remains unchanged. The representatives of the supreme authority of Lithuania did not appear at the celebration of $70^{\text {th }}$ anniversary of Victory in the Kremlin in 2015. "The Great Patriotic War - is it really of our Homeland?", "projected homeland", "war after war" - a rejection is based on such and similar wordings - statements $^{3}$. The

${ }^{2}$ Herein the pro-Lithuanian memories are called the memories that protect the interests of Lithuanian speakers who perceive themselves as a sovereign unit and want to be as such.

${ }^{3}$ For example, a series of publications on the official website of the Seimas of the Republic of Lithuania War after War (Lietuvos Respublikos Seimas, [interactive], in: www3.lrs.lt/pls/inter/www_tv.show?id=6521,1,19, (04/11/2016)); Movable exhibition of the Museum of Genocide Victims of Genocide and Resistence Research Center of Lithuania War after War: Armed anti-Soviet Resistance in Lithuania in 1944-1953, prepared in 2004 (Lietuvos gyventoju genocido ir rezistencijos tyrimo centras, [interactive], in: concept of the Great Patriotic War itself was abandoned even earlier. In governmental acts the concept disappeared shortly after $1990^{4}$. In 1990-1993 the Soviet monuments also disappeared: i.e. the statues to the Victory, the army liberator and the Soviet partisans were dismantled. After 1999 part of the statues once again stood on their foot, only in another environment and context - i.e. in Grūtas Park - a sculpture garden (museum) of the Soviet era statues. Thus, not only the Great Patriotic War, but also the topics of the Second World War are nowadays left outside the limits of proLithuanian memories.

In Russia it has taken the third way. The myth, which was a bit forgotten for a moment after 1991, got its second breath in Putin's Russia. Its contemporary significance can be described as follows: "Although it was created and articulated in the Soviet era, nowadays this myth has acquired new forms and goals of political use and has become a peculiar centre of political gravitation in the field of memory. [...] It has become an important ideological backbone for the political elite who is seeking to restore the power of Russia. First of all, it was used to motivate the inner Russian audience, for example, to construct the emotional fundamentals of being proud of "the Great Russia". Subsequently, it began to be used as one of the levers of foreign policy",5.

Getting back to Lithuanian contexts and the Great Patriotic War monuments built during the Soviet era, not all of them disappeared in 1990-1993. One group of them has become an obvious exception. They are the cemeteries of the Soviet soldiers. Their number, as compared to the Soviet period, has changed slightly, according to the official

http://genocid.lt/tuskulenai/lt/1144/a/, (04/11/2016-)); Delfi TV documentary series War after War, prepared in 2014-2015 (Delfi TV, [interactive], in: www.delfi.lt/video/laidos/dokumentika/pamatyk-visasdokumentinio-ciklo-karas-po-karo-

serijas.d?id=66810904\#vid=66583680, $(04 / 11 / 2016))$. See also Ceslovas Iškauskas, "The Great Patriotic War - Is it really of our Homeland?”, in: Čslovas Iškauskas. Žurnalistinis dienoraštis, 21/06/2011, [interactive], in: www.iskauskas.lt/page/107/, (04/11/2016).

${ }^{4}$ E.g., Resolution No 230 of the Government of the Republic of Lithuania of 12/06/1991 Regarding the Procedure for Issuance of the Documents to the Inhabitants of the Republic of Lithuania on their Sending for Forced Labour, Living in Ghettoes and Other Places of Imprisonment During the World War II; Resolution No 327 of the Government of the Republic of Lithuania of 17/08/1991 Regarding Compensation for Material Damage to the Individuals who Were Sent for Forced Labour During the World War II and the Individuals who were Illegally Evicted from One Place of Lithuania to another in 1951-1952.

5 Karolis Zikaras, "Propaganda", in: Kariai. Betonas. Mitas. Antrojo pasaulinio karo Sovietu Sajungos kariu palaidojimo vietos Lietuvoje, Vilnius: Vilniaus universiteto leidykla, 2016, p. 118. More information on the meaning and functions of myth in present-day Russia, see Ibid. p. 118-137. 
(heritage protection) data, in 1990 there were 167 such cemeteries and in 2016 - 160. One feature of these monuments has become the reason for such immunity - i.e. the bodies are their integral part. This is the reason why they have become not only the matter of memory but also the issue of moral and international obligations (the Geneva Convention (regarding war victims) and etc.). But let's start with another question - what is the nature of these places, what are they?

The Load. The burial places of the Soviet soldiers of the Second World War are not only cemeteries, but also memorials. More precisely, they are primarily memorials, where bodies are used as components of the memorial, as their 'building material' (in terms of meaning formation). Dead soldiers were already buried once in random places depending on the circumstances in the outer woods, fields, at the approaches of the railway stations, in the yards, squares, and burial grounds. Such were the realities of the wartime. In 1945 the creation of secondary military burial places in Lithuanian SSR began. There were two reasons for their occurrence. The first one was utilitarian. It was necessary to address the issue of optimization of the number of burial grounds and their care, and this was done by merging a few or several burial grounds into one. The second reason was ideological one. The myth of the Great Patriotic War, born during the Second World War, did not sag - it experienced transformations, although it was not always accepted with equal enthusiasm by the ones sitting in the Kremlin, but it continued to deepen its roots and strengthened its position as one of the main memories of the Soviet society. The manifestations of the myth were needed and not only the ones expressed in words, in written form or performed in ceremonies, but also the ones materially expressed in landscape. The secondary burial places were not chosen spontaneously, on the contrary, they were created by following the best traditions of memorial building. Usually, they were arranged in the original military burial places by choosing the ones the localisation of which was most suitable for memorial practices. The remains of the 'non-viable' burial grounds were moved to the newly built ones. In this way, a new object was created - the secondary burial places or the cemeteries of the Soviet soldiers of the Great Patriotic War. The transformation of the original burial places into the secondary ones has essentially changed the object itself. The burial places became less dependent on historical circumstances and came closer to what might be called an ideal memorial place. The drive to form such places in the Lithuanian SSR continued until 1956. The reburial of remains and the change in the network of the places continued later on, throughout the Soviet period, but on a considerably smaller scale.
The bodies. The bodies of the deceased were a fundamental component of the cemeteries of the Soviet soldiers of the Great Patriotic War, and they were the factor which gave the necessary significance to this memorial. The bodies were needed as a fact, as a factor which could bring emotional background and value. However, in some sense and to a certain extent the bodies themselves lost their individuality, and were depersonalised due to their reburial in such sites. Not only utilitarian aspects (e.g. distance or capacity) determined the redistribution of the remains. The bodies were moved from one place to another to bring greater significance or additional meanings to the location. In 1945 the bodies of the soldiers fallen near Klaipeda and Kuršas were transferred to Kartena (Kretinga distric). Such long journey from Kuršas was needed because the remains were special - it was the remains of the soldiers of the 16th Lithuanian rifle division. The bodies were also moved on the occasions of the Soviet anniversaries. In 1954 and 1955 on the occasion of 10th anniversary of the liberation of Vilnius and 15th anniversary of the foundation of the Lithuanian SSR, the remains of the Soviet partisans were solemnly displaced to the war graves of Vilnius and Kaunas. The place and its propagandial weight as well as the ceremonies were of higher significance and more important than the peace of the deceased. In addition, the burying of the bodies in military burial places was also performed trying to veil the identities and submerge them in the mass of other bodies and other meanings. Such were the remains of the ones dead in a postwar period or politically unfavourable remains, which we will talk about later. Of course, the individuals were not completely forgotten: relatives were looking for their next of kin, they brought flowers and put them on their burial grounds next to the engraved names, while local mass media introduced heroic and instructive military stories. But the memorials with identical monuments, repetitive fonts of engraved letters, and a plenty of names merging with each other remained indifferent and cold to the buried bodies. For propaganda purposes, it was enough to declare that the remains of the soldier of the Soviet Union were here, no matter who he was. It was the play with categories rather than individualities. Resource for propaganda - such was the fate of bodies in memorials. The names were considered significant only if it was the hero of the Soviet Union.

Localisation. Let's come back to the thought that the transformation of the original burial places into the secondary ones has essentially changed the object itself. First of all, their localisation has been changed and from the objects of fields, outskirts and villages they have become the objects of small towns and cities. In 1973 
there were 176 cemeteries of the Soviet soldiers of the Great Patriotic War in the Lithuanian SSR ${ }^{6}$ : about $50 \%$ of them were located in cities and their approaches, $38 \%-$ in small towns, and $11 \%$ - in villages and one cemetery was in the forest. This is related to another obvious tendency: the localisation of the secondary burial places was perfectly coordinated with the administrativeterritorial division of the Lithuanian SSR. In 1949 there were 41 counties in the Lithuanian SSR - all county centers (central settlements of the counties) (100\% of them) had cemeteries of the Soviet soldiers of the Great Patriotic War. The bodies from the original places were gathered to the secondary burial places and it resulted in reduction of the Soviet military burial grounds in the Lithuanian SSR. However, this heritage was quite enough to involve the whole Lithuania through the administrative points and the territories they cover. As a result, territorial and propaganda networks were formed from chaotically scattered burial grounds. The process of creating secondary burial places and their results should be treated as concentration and optimization for even greater impact/memorial significance. Generally speaking, not only the accessibility and approachability are necessary for memorial practices, but also the aura of celebration. They are not intended for everyday or domestic use, but for use through celebrations, for ceremonies, to create the feeling of "holiness", therefore being in such places of memorial practices has to rise people to quite different dimension and create different emotions than we encounter in everyday life. Only then the practice or place starts functioning as memorial. Thus, the memorial place should not be neither too frequent, not to become a daily picture and melt in everyday horizon, nor too rare, to disrupt the involvement of all desired society.

Topics. The epic of the Great Patriotic War could have many thematic expressions ${ }^{7}$, but most of the Great Patriotic War heritage and memorial places could embody only one or two themes - separate episodes of the epic. The situation was quite different with burial

${ }^{6}$ The places were identified on the basis of the list of cultural monuments of the Lithuanian SSR, where the objects having the status of a cultural monument (later on - historiccultural monument) were enrolled. The actual number of the burial places of the Soviet soldiers of the Second World War did not coincide completely with the data of the list: not all the places had a monument status, and there actually were a bit more of them than it was presented in the list. Secondly, some places were erroneously assigned to the cemeteries of the Soviet soldiers of the Great Patriotic War and etc. However, from all possible sources, this one is the most accurate, causing least doubt and confusion.

7 For more information see Salvijus Kulevičius, "Vietos", in: Kariai. Betonas. Mitas. Antrojo pasaulinio karo Sovietu Sajungos kariu palaidojimo vietos Lietuvoje, Vilnius: Vilniaus universiteto leidykla, 2016, p. 69-79. places of soldiers. These places were able to convey a very wide range of topics of the Great Patriotic War, such as: (a) heroism, (b) Victory, (c) liberators, (d) falsity and cruelty of an enemy, (e) Lithuanian contribution, and etc. It is understandable that all potential topics have never been activated or exhibited at the same time, because like in any other case of politicized memory, only the most suitable topics are purposefully selected and developed. Both the thematic capacity and concentration made this place the best of all the existing or possible, historic-authentic or newly created memorial places of manifestation of the Great Patriotic War. Probably only Victory Memorials could also have such advantages. It was also very convenient that this garner allowed the inconvenient topics die and rise the new relevant topics without causing any damage to the place itself. In such a way the place was protected from fluctuations in memory policy and threat that in case of the change in memory policy (the aspects and accents of the image of war), it could lose their significance. It always remained a significant place.

'The Red Corner'. Approximately in 1956, the first and greatest wave of reburial of soldiers subsided. But the bodies continued to flow. And it was not only the remains of the soldiers fallen during the Second World War. (a) In 1954 the displacement of the remains of the Soviet partisans to the cemeteries of the Soviet soldiers of the Great Patriotic War intensified in the Lithuanian SSR. In at least $13 \%{ }^{8}$ of such cemeteries the remains of the Soviet partisans were buried next to the remains of the soldiers or at least they were mentioned in the memorial plaques. Most often there were only several such burials - 'just for the smell'. (b) The individuals who died in 1945-1953 Lithuanian guerrilla war, also the Soviet soldiers, People's Defence Platoons (destroyers), the Soviet activists and their family members were buried in at least $17 \%$ of such places. (c) In the $70-80$ s the Soviet soldiers who died in various circumstances and did not belong to the generations that could participate in the Second World War were buried in these places. For example, in 1979-1989 the victims of the war in Afghanistan were buried there. (d) The veterans of the Great Patriotic War who died after 1945 also were buried there. There also were other groups who were buried there, for instance, (e) the Bolshevik fighters or the ones who joined them during the struggles for independence of

${ }^{8}$ Here and elsewhere the data are calculated on the basis of existing records on memorial plaques (on the grounds of the pictures found in the databases of the Public Institution Military Heritage Institute (http://db.militaryheritage.eu/titulinis) and the Register of Cultural Properties of the Republic of Lithuania (http://kvr.kpd.lt/ \# / static-heritage-search). The records appeared in different periods, both in the Soviet times and during the reconstructions that were carried out after1990. The source is not reliable, but it is hoped that it does not distort the overall proportions too much. 
Lithuania in the period from 1918 to 1920 or (f) the bodies of the Soviet collaborators who were killed by Lithuanians during the June uprising in 1941.

On the one hand, the cemeteries of the Soviet soldiers of the Great Patriotic War have become a shelter for other bodies, on the other hand, these 'other' bodies added some new aspects and meanings to these places themselves. Thus, the cemetery of the Soviet soldiers of the Great Patriotic War, in its factual content, is a bit more complex derivative than it is said under its title. In this place the remains of people dead in different times and in different circumstances have intermingled into one idea that emerges above history and testifies the immortality of the revolutionary thought and the victory of the Soviet system in general. It was the Soviet 'red corner' in the landscape - the materialization of specific narratives and 'universal' Soviet 'cosmogonic' myths through bodies, forms of memorials and records.

Fabrication. If we rely on the image of the past depicted through the cemeteries of the Soviet soldiers of the Great Patriotic War and other memorial sites, then we shall come to the idea that the Lithuanian Soviet partisans had to play a significant role in the Great Patriotic War. During formation process of secondary burial places, the bodies of the more prominent partisans were of high significance - their remains were transported from various places of Lithuania to the main memorial places of the Great Patriotic War in Vilnius and Kaunas. The monuments to partisans appeared in cities and towns: in Druskininkai in 1952, in Zarasai in 1955, in Ukmergè in 1976, in Alytus in 1977, in Vilnius in 1983. Historical sites related to partisans were given a memorial status, they were invigorated by making them a part of heritage, for instance, stone monuments were built, memorial plaques were laid and they were recognised as cultural monuments. In the 1970s a drive to restore partisan dugouts began: in 1973 the complex in Rūdiškiai forest was restored, in 1974 - in Rūdninkai forest and in 1975 - in Antanai forest. However, the facts show a somewhat different contribution and weight: in the legendary partisan hideout in Rūdninkai forest the Lithuanians accounted only for $7 \%$ of the total of all fighters (76 out of 1157); in the whole Lithuania Lithuanians accounted for $36 \%$ (1386 out of 3904) of the total fighters ${ }^{9}$.

This is just one 'inaccuracy' from the narrations of the cemeteries of the Soviet soldiers of the Great Patriotic War and the Great Patriotic War. David Lowenthal calls it a fabrication of heritage $e^{10}$. Not the heritage itself is being

9 Rimantas Zizas, Sovietiniai partizanai Lietuvoje 1941-1944 m., Vilnius: Lietuvos istorijos instituto leidykla, 2014, p. 142-144, 545-546.

${ }^{10}$ See David Lowenthal, "Fabricating Heritage", in: History and Memory, 1998, vol. 10, No. 1, p. 5-24. fabricated, but the past is being fabricated by heritage. The heritage is a distorted past. And this is not an evil or immorality. Fabrication of heritage means making it relevant, being of service to identity and other fundamental issues of social environment. And only the heritage is able to perform this function - it is its nature and character, that's why it is necessary and useful, this is the reason why it is adored by society. Simply put, all this can be called a memory, and the heritage can be considered as its garner and manifestations. The cemeteries of the Soviet soldiers of the Great Patriotic War is a historical place, which existed in accordance with the laws described by D. Lowenthal, this place absorbed and at the same time expressed the Soviet historical images and the Soviet values.

Status. In 1948 the first post-war document concerning protection of cultural heritage (in he terminology of that time - cultural monuments) was issued in the Soviet Union. It confirmed the importance of the memory of the Great Patriotic War. Only a few historical specifics were distinguished and identified by this document, one of which was this war: "[...] the following historical monuments: buildings and places related to the most significant events of the peoples of the USSR, the revolutionary movement, the civil and Great Patriotic wars, socialism construction; the memorial monuments related to the life and activities of prominent statesmen and politicians, folk heroes, noted scientists, artists and technicians, their graves; military technology, economy and household monuments should be protected by the state"11. The exaltation of the Great Patriotic War along with the construction of a revolutionary movement and socialism confirmed the significance given to the event - its undoubted importance both for the creation of the Soviet state (historical significance) and for the Soviet propaganda (ideological significance). If we take a look at other documents regulating the heritage of the Soviet era, we will see that cultural monuments were without any obliquities considered as instruments of 'political educational' activities or 'patriotic, ideological - moral and international' education ${ }^{12}$. This was also expected from the relics of the Great Patriotic War.

Eventually the cemetery of the Soviet soldiers of the Great Patriotic War became not only the burial ground and memorial, but also the heritage - a value that

11 “Приложение к постановлению Совета Министров СССР № 3898 от 14 октября 1948 г. Положение об охране памятников культуры”, in: Инструкиия о порядке учета, регистрации, содержания и реставрации памятников архитектуры, состоящих под государственной охраной, Москва, 1949, с. 6 [стат. 9].

${ }_{12}$ Ibid., c. 19 [стат. 38]; Закон Союза Советских Социалистических Республик об охране и использовании памятников истории и культуры, Москва, 1976, с. 9 [стат. 13]. 
is considered so special that it must be protected and passed on to future generations ${ }^{13}$. Heritage is a material or tangible side of the symbol embodying suitable meanings, and not just general meanings, but the meanings that are often foundational or essential to the existence of a group. This is the feature of heritage on the grounds of which its protection is publicly announced, thus publicly indicating and showing its importance (the importance is created through prohibitions and threats, because not to everyone can be self-evident and 'naturally' perceived that it is a value), and really hoping to physically preserve one's symbols. In addition, heritage is a certain coercion against the historical time and descendants: current generations make decisions on behalf of future generations on what should be valuable, meaningful and relevant to them, hoping that future generations will willingly inherit the environment that has already been created as well as the duty to protect those meanings without asking them whether they want it or not. This apriority is the hope of the present inhabitants to secure their immortality and memory in the future through the continuity of their ideas/meanings.

Imaginary or Real Threats. The study of the genesis of the cemeteries of the Soviet soldiers of the Great Patriotic War has revealed their cunning nature: these places are the traps for memory and the hotbeds of propaganda, they have been created as such from the first body and from the first stone. In about 1990, in Lithuania the instigators of such hotbeds disappeared for some time... In 2000 the works were started in these places. Concrete posts were changed, the bodies were recalculated and new records appeared. The reconstruction was carried out on the initiative of the Russian Federation and it was funded by them. The works were performed in accordance with their images and expectations, to the extent they were allowed (forbidden) to spread out by the guards of the Lithuanian heritage, memory and statehood (or were left unnoticed by them).

Concepts. After the reconstruction of memorials a new formulation appeared - i.e. the record The cemetery of the Soviet soldiers who died in the war of 1941-1945. They differ from the concepts used during the Soviet era (the cemetery of the Soviet soldiers of the Great Patriotic War) and official Lithuanian terminology (the burial place of Soviet soldiers of the Second World War); the latter concept was created in the environment of heritage

${ }^{13}$ At the beginning in 1948 this message was only an empty declaration. In the Lithuanian SSR it was implemented only after twenty years, in 1969 and 1970, when the first lists of historical monuments were approved. This could be influenced by both slow or purposefully halted formation of the heritage protection system in the socialistic country, and the fluctuations related to the topic of the Great Patriotic War itself. A more stable and clearer period of memory policy was achieved in Brezhnev's epoch. protection institutions of Lithuania in 2010 and used in the Register of Cultural Property of the Republic of Lithuania). The record no longer contains the term the Great patriotic War, which is absolutely strange to Lithuanians and do not fit with political correctness. But the truth is that only the sound of the term was changed, not its content. The Great Patriotic War speaks about the war that began in 1941, namely in 1941 and not in 1939. The concept is very wise and insidious, because it allows to reticent a series of events, when the Soviets occupied other countries in the shade of the Second World War. By replacing the concept of the Great Patriotic War with the words the war of 1941-1945 no changes were made the meaning remained the same. It was just an adaptation to new circumstances. Perhaps this was a painful submission (the concept, which itself was a story, symbol and place of memory, was sacrificed), but it overcame the dominant narrative. Basically, the title the burial place of Soviet soldiers of the Second World War has remained a professional jargon, which is encountered only in a narrow scope of specialists and in the documents issued or created by them. While its alternative title the cemetery of the Soviet soldiers who died in the war of 1941-1945 is depicted in the landscape such record can be met almost in every military burial place. If we were to learn the history of the Second World War from the military burial places of the Soviet Union, we would assume that this war began in 1941. Having in mind the network of such places created in Soviet times and the fact that it has remained so far without major losses, it is hardly possible to find a larger edition (in terms of accessibility) about the Second World War in Lithuania.

Numbers. There is another paradox. Nowadays the places are in a hostile environment: in pro-Lithuanian environment they are bluntly identified as a foreign body or at least are unable to unfold as places of memory of the dominant groups, simply said, to serve the purpose for which they were created. However, in a hostile environment quite different processes took place than it could be expected: instead of diminishing in size, the number of places increased. The trustee of the Russian Embassy in Lithuania, public institution Military Heritage Institute, presented its own collection ${ }^{14}$ of the military burial sites of the Soviet Union. It consists of the objects of three categories - the Soviet military cemeteries, prisoner-of-war cemeteries and memorials. Let's present some statistics and give some criticism. Let's treat that the Soviet military cemeteries are the burial places of the Soviet soldiers of the Second World War. In the official cultural heritage documents the

${ }^{14}$ Burial Grounds of the Soviet Soldiers in the Republic of Lithuania, in: Military Heritage Institute, [interactive], in: http://db.militaryheritage.eu/titulinis, (04/11/2016). 
following numbers of the burial places of the Soviet soldiers of the Second World War were given: in 1973 there were 176 such places, in 1990 - 167 and in $2016-$ 160. In 2010 the Institute provided a different number 213. It means that the number has increased by 46 places or $22 \%$ if compared to the number presented in 1990. Isn't it a big increase in quantity? How could the calculation and inventory of the most valuable folk assets, its pride, be performed so absentmindedly in the Soviet time? We have to come back to D. Lowenthal's thoughts. The heritage does not like criticism: the nature of heritage, whatever it is, official or unofficial, national or of informal groups, is to fabricate, and criticism reveals this. Are the new places, found and presented by the Institute, real? Let's check out:

- In at least 8 of them only one soldier is buried they should be considered as graves, not cemeteries ${ }^{15}$; moreover, the same could be said about 7 more places, where $2-4$ individuals are buried ${ }^{16}$;

- at least 7 of them are the sites of events (place of death, the site of fighting), but not the burial places, there are probably no bodies buried at all ${ }^{17}$;

- in at least 11 of them the bodies of the people related to Bolshevik invasion in 1919, removal of the Soviet activists (June Uprising) and partisan wars in 1944-1953, but not the Great Patriotic War are buried, i.e. the remains of the Soviet partisans, Soviet activists, People's Defence Platoons (destroyers) or victims of the Holocaust, but not the soldiers are buried there - these are the burial grounds of other bodies or the number of these other bodies is not smaller than the number of the remains of the soldiers fallen during the Second World War.

Fabrication again. Based on the descriptions of the places, we can presume that the creators of the new collection should be aware of the real characteristics of these places. Thus, these inaccuracies are not a matter of ignorance, but rather a conscious action. Hyperbolysis or attributing the things to the categories to which they do not really belong to (the bodies are invented to be where they do not actually exist; the bodies are attributed to the groups they do not belong to) - such is the nature of more than half of the places 'discovered' by the Institute. The heritage is fabricated not without purpose.

15 "Burial Grounds of the Soviet Soldiers in the Republic of Lithuania", No. 13-02, No. 30-01, No. 30-04, No. 30-06, No. 45-10, No. 50-03, No. 55-01, No. 58-11, [interactive], in: http://db.militaryheritage.eu/titulinis, (accessed on $04 / 11 / 2016$ ).

16 "Burial Grounds of the Soviet Soldiers in the Republic of Lithuania", No. 24-05, No. 24-08, No. 27-01, No. 30-05, No. 43-02, No. 45-07, No. 58-09, [interactive], in: http://db.militaryheritage.eu/titulinis, (04/11/2016).

17 "Burial Grounds of the Soviet Soldiers in the Republic of Lithuania", No. 12-03, No. 12-04, No. 38-06, No. 39-01, No. 46-01, No. 46-03, No. 52-05, [interactive], in: http://db.militaryheritage.eu/titulinis, (04/11/2016).
It is done for the benefit. The collection silently changes the map of the Soviet military burial places created during the Soviet times in Lithuania. In the Soviet era, the aim was to create a high quality network of places, that the burial grounds would function as places of memory and memorials, and in such case a large number of places is not always effective, there should be neither too many nor too little of them. Now the quantity is the subject of interest - to discover/invent as many heritage of the Great Patriotic War in the landscape of Lithuania as possible. Since the topic of the Great Patriotic War is a taboo in pro-Lithuanian environment and territory, relatively except the military burial places, its signs are embedded and propagated precisely through them.

Meanwhile in public space the trustee of the Russian Embassy in Lithuania PbI Military Heritage Institute represents itself as an institution which grounds its activities on expert judgements ("according to the experts of the institute...") 18 and even considers itself almost a scientific institution: "The Military Heritage Institute is a social, non-commercial organization, which was founded by the enthusiast of military history [...] The organization carries out scientific, applied and popularization of science projects on the topic of military history ${ }^{19 "}$. Again, we must remember the nature and theory of heritage. The purpose of heritage is to make the past more acceptable and useful (to be of service to us), but also at the same time it has to be the one we could unconditionally trust. We believe in the trueness of its forms, meanings and the image of the past being created, forgetting that these forms, meanings and images have just been created by us and created to best meet our present needs and expectations. It seems that modern people are more confident in the past than in the present, thus they look for confirmations in the past and when they fail to find them there, they create them by using heritage ${ }^{20}$. The heritage is a self-delusion. To shield this treachery, heritage has an element of certainty, which is called an authenticity, and it also uses the standing of science. We consider them both to be reliable, thus the heritage should also gain this reliability. So, the Institute does not invent anything new. It plays regular heritage games, in fact, it plays unsubtly and non-ingeniously or more insolently than others.

Meanings. If the fabrication of databases was made 'on paper', of landscape it was made 'in stone'. After the reconstruction, very specific and unquestionable records

18 "The Project of Commemoration of the Victims of the World War II", in: Military Heritage Institute, [interactive], in: www.militaryheritage.eu/naujienos/antrojo-pasaulinio-karozuvusiuju-kariu-iamzinimo-projektas, (04/11/2016).

19 "About us", in: Military Heritage Institute, [interactive], in: www.militaryheritage.eu/apie, (04/11/2016).

20 See Salvijus Kulevičius, "Nature and Mission of Heritage in Modernity: Impacts of Nationalism", in: Historical and Cultural Studies / Iсторико-культурні студіi, 2015, No. 1, Vol. 2, p. 3-8, [interactive], in: www.academia.edu/24931343/Nature_and_Mission_of_Heritag e_in_Modernity_Impacts_of_Nationalism_EN_, (04/11/2016). 
appeared in the places suspicious for us- i.e. "The Cemetery of the Soviet Soldiers Who Died in the War of 1941-1945". Attributing the thing to a certain category or giving a name to it is not just a simple procedure, because it is the way the meanings are created. Today the map of the places of the Great Patriotic War is changing not only quantitatively. New meaningful accents also appear. For instance, in the collection created by the Institute, not like in any former or existing list, the frontier-guard of 1941 becomes a very striking figure. In the descriptions of the places this character is mentioned probably 15 times $^{21}$. This character is also more frequently met in stone engravings. Having put these points on the map, it becomes very clear where the borders of the USSR ended in 1941 and where was Lithuania at that time. The military sites also become the territory marking sites. We do not claim that the motive of the frontier-guard is highlighted consciously and tendentiously, we have no basis for such assertion, but this creates preconditions for ideologized interpretations.

Another example. During the Soviet times the attitude towards the places related to post-war events was quite reserved. There were such places, they were made memorial, but there was no any rush to make them public or make them the object of national interest, for example to declare them cultural monuments. The authors of the new collection were bolder - at least 7 such places were included into the collection, some of them were reconstructed. Despite the fact that such places still propagate the Soviet interpretations and that these approaches are now considered totally unacceptable, they are still in circulation. We enter the place having the title The Cemetery of the Soviet Soldiers Who Died in the War of 19411945" or The Cemetery for Soviet Soldiers and Victims of Fascism Who Died in the War of 1941-1945, such inscriptions meet us at the entrance, and when we go further we find other notes, such as: "unknown folk defender"; "the secretary of country-side district/ 1907-1941"; "the secretary of a primary party organization of rural district/1904-1946"; "newcomer/1885-1946" and etc. The pro-Lithuanian group speaks about the war after war, but probably they have quite different illustrations in mind. If those who died after 1945 are the victims, their offenders are the fascists, and the events that happened afterwards should be understood as the continuation of the war against fascism, in pro-Lithuanian perspective everything would look quite different, the first ones would be People's Defence Platoons (destroyers) or the guilty ones and sneaks, the second - the heroes, forest brothers and it was the struggle against the occupants and for freedom. These two stories are not parallel. They basically deny each other, and the compromise is not possible here. The problem is that the issue is based on ultimate oppositions such as good and evil, the hero

21 "Burial Grounds of the Soviet Soldiers in the Republic of Lithuania", No. 12-03, No. 22-03, No. 24-01, No. 24-07, No. 40-06, No. 50-08, No. 01-04, No. 14-04, No. 42-07, No. 42-08, No. 50-04, No. 50-05, No. 50-07, No. 50-09, No. 50-10, [interactive], in: http://db.militaryheritage.eu/titulinis, (04/11/2016). and sneak, and what one side indicates as good, the other considers the same phenomenon or character as an absolute evil. Therefore, these places with their current design (inherited from the Soviet era and emerging after new reconstructions) illustrate another myth about the war after war - the Soviet and the one being created in the present-day Russia. These places are still the embodiment of the myth, which is alive, alien to Lithuanians and destroys their narrative.

Conclusions. 1. The secondary nature of the cemeteries of the Soviet soldiers of the Great Patriotic War allowed creating the places, which could be compatible with propaganda whims and have everything that is needed for a perfect monument. The sites of victorious battles, heroic death and other similar historical places could perfectly suit for the creation of the myth of the Great Patriotic War, but all these places had one drawback - they were remote and rare. They were bound to the location of the initial events. While the secondary establishment and abundance of available resources (i.e. bodies) allowed founding the cemeteries of the Soviet soldiers of the Great Patriotic War in necessary locations, to the extent necessary and the ones that were needed. These cemeteries did not have to obey the history, on the contrary, the history- politically and propogandically "fair" narrative was created by them. They embodied the best features of the phenomenon of heritage the society trusted them and believed in them, and they themselves were able to create the stories needed for politics of memory, even fake stories, if necessary.

2. In 1990 the myth of the Great Patriotic War became alien in Lithuania. The majority of its material signs were destroyed or devaluated, but the burial places of soldiers remained. And they remained in all extent, starting with the network, monuments and ending with symbols. In about 2000 they became the place of action to the group, which we conditionally can call the circle of the Russian Embassy in Lithuania. The reconstruction of the places, which is carried out on their intention, evidences their desire to preserve the myth of the Great Patriotic War by adapting to the current circumstances and further embed these places in the landscape of Lithuania. It would be unfair to evaluate the latter processes unambiguously and attribute these places only to the field of direct targeted propaganda or the desire to make influence. For example, the factor of commercial benefit also cannot be rejected - the more places, the more activities and the more funds can be requested for execution of these activities. However, whatever the intentions are, the potential of these places is to compete with the present-day great Lithuanian narratives or to deny them. The same phenomenon is considered as occupation and evil by the ones and as liberation and Victory by the others. Such is the nature of these places and it seems that it is unchangeable.

The translation of the publication was supported by the funds of Juozas Sidas which were allocated at the Faculty of History for the stimulation of history research and studies. 